\title{
The Effect of WhatsApp in Blended Learning on English as Foreign Language (EFL) Undergraduate Students' Reading Comprehension
}

\author{
Liya Astarilla and Dede Warman \\ STMIK-AMIK Riau \\ Pekanbaru, Indonesia \\ liya.astarilla@gmail.com
}

\begin{abstract}
This research aimed to investigate the effect of WhatsApp in blended learning on EFL undergraduate students' reading comprehension ability. This was an experimental research with participants of students at second semester at one private college in Pekanbaru-Riau, Indonesia. The 20 students were randomly and equally assigned to the experimental group and another 20 students as the control group. The instrument of this research was reading comprehension test in form of multiple choices, used as pre-test and post-test to asses the participants' reading comprehension ability in both experimental and control group. The result of this research found that there was a significant effect in blended learning through WhatsApp on EFL undergraduate students' reading comprehension. The students who used WhatsApp in blended learning environment showed higher scores than those who did not. The experimental group read more texts and interacted with their peers via WhatsApp, therefore it enhanced their reading comprehension. In conclusion, blended learning through WhatsApp had contributed to the achievement of EFL undergraduate students' reading comprehension.
\end{abstract}

Keywords- WhatsApp; blended learning; reading comprehension.

\section{INTRODUCTION}

In this globalization era, undergraduate student should have English language competency in order to compete in the working world because nowadays English has become a common communication tool in the world, included in Indonesia. Furthermore, since Asian Economic Community has released in 2015, English become a vital weapon for the undergraduate students if they want to compete in international job market. Otherwise, they will leave behind from those who have English skills. According to Indonesian Qualification Framework, one of the main goals of it is to increase Indonesian human resources that have quality and international competitiveness. So that, every undergraduate student should prepare themselves and master English skills well. In fact, one of the major problems for EFL students in learning a foreign language is the poor English reading comprehension ability of EFL students.

Moreover, reading is one of the skills that the undergraduate students should master in learning English. Reading is the common source to achieve and develop students' knowledge and skills in order to improve their knowledge of foreign language and their ability to access the world information which is commonly provided in the form of electronic media and printed materials such as textbooks, journals, articles, newspaper, magazines, email, etc. The students need to read to gather information for both their academic success and their career. Farhady, et al. have stated that "reading is the most important of all skills for most language learners in general and for EFL learner in particular' [1]. In other words, reading is the basis of instruction in all aspects of language learning. Reading is a thinking process for the students to comprehend or analyze a text or a paragraph that encourages them to gain more information from what they are reading. Neufeld [2] states that comprehension is the process of constructing a supportable understanding of a text. He added that comprehension involves two important features: being actively involved with the text and using appropriate background knowledge to interpret the text. Therefore, when students comprehend the material their brain works to try to make meaning of information presented. According to Klingner [3] reading comprehension is a multi-component, highly complex process that involves many interactions between readers and what they bring to the text as well as variable related to the text. Based on the definition, it can be concluded that reading comprehension is a process of interaction between readers' background knowledge with the information from the text while they are reading.

The continuing advancement of information and communication technology has contributed to new opportunities to enhance the accessibility and quality of education. The evolution of mobile technologies has affected students' learning styles and teaching methods in educational environment where mobile devices have been applied. One of them is the using of mobile learning in teaching and learning activities. The advantages of mobile learning include the convenience that comes with small and lightweight devices, the availability of space and time for learning, the adaptability of content according to individual needs, and the facilitation of sustained connections between students and teachers. Geddes [4] suggests that mobile learning can extend opportunities for learning that can enable better use of time and promote flexibility. Mikic, et al. [5] believed that mobile learning has created a new learning environment that enables learners, 
through action learning aids, teaching materials, teachers and other learners, to learn at anytime and anywhere. It means that the fundamental feature of mobile learning is its mobility since the students can learn through it anywhere and anytime. Kukulska et al. [6] find mobile learning provided EFL students with substantial contextual opportunities that extended outside the classroom. It is not only stimulated collaboration and interaction between students, but also enhanced their context-awareness about their surrounding environment. Klopfer, et al. [7] suggests there are considerations of mobile phones in mobile learning such as portability, social interactivity, context sensitivity, connectivity, and individuality.

Furthermore, the students' reading proficiency improved when they are also exposed to online texts. Szymanska and Kaczmarek [7] argued that in order to make learners become proficient readers in a foreign language, they need to have access to online texts which can help them to respond in an authentic way to what they have read. Reading on the net can also help learners be able to analyze the text by themselves, reflect on it and try to comprehend it independent of asking for help from a teacher. They also concluded that learners improved in a blended learning reading course using both printed and online texts in terms of both recall and comprehension of the texts.

Mobile devices or applications on smartphone or android are used in mobile learning have great potential for educational purposes. Although there are many useful mobile phone application can be used teachers, not all of them completely used by students and yet appropriate for learning reading. The most ubiquitous application on smartphone among students is WhatsApp. It was launched in California in 2009 by Jan Koum and Brian Acton. WhatsApp is currently the biggest online messenger app on the market. It is a smartphones, tablets, and PCs application for instant messaging that provides several features. It can send message, file, document, image, audio, video, and location. One of the great features of WhatsApp is its ability to facilitate communication via group. It uses the internet to send message or document. The cost of using it is significantly less than texting. This application is used ubiquitous for almost all mobile phone devices even for the students. Realizing this phenomenon, the researcher encouraged to apply mobile learning in blended learning through WhatsApp for her students. The objective of this research was to know the effect of WhatsApp in blended learning on EFL undergraduate students' reading comprehension.

\section{METHOD}

This study is a kind of an experimental research. It was conducted to find out how effective is WhatsApp in blended learning on EFL undergraduate students' reading comprehension. The participants of this study consisted of 40 students of the second semester at one private college in Pekanbaru, Riau, Indonesia, 20 students were randomly and equally assigned to the the experimental group and the other students as a control group. Concerning the experience of using WhatsApp in blended learning, none of the students has learned it before. This research was conducted in the second semester of 2016 academic year. Their ages range from eighteen to twenty. The students were enrolled in English II course, Reading class. They met in class once a week. Each time covered 100 minutes. The length of the semester was 14 weeks, but the researcher only gave treatment during 8 meetings.

This research used pre-test and post-test control group design which both of groups got pre-test in the first meeting ang post-test in the last meeting. The instrumentation of this research was multiple choice tests which consist of 40 questions and the time around 60 minutes. Pre-test aimed to know students' reading comprehension ability of the text generally and post-test aimed to know students' reading comprehension of text after treatments. For the treatment, the experimental group received instruction in the classroom and had individual or group assignment through WhatsApp whereas the control group only had the instruction and the assignment in conventional method. During the treatment, the participants in experimental group were exposed with many kinds of texts from the researcher via WhatsApp. The students also could learn individually involved reading activities anywhere and anytime through discussion with their friends in a WhatsApp group chat. After conducting the treatment, a post-test of reading comprehension was administered, then the participants' achievement in both tests were compared to see if blended learning through WhatsApp contributes significantly to students' reading comprehension. The results of the pre-rest and post-test also were compared to see if there was any improvement in the students' reading comprehension performance.

In this research, the researcher focused on content validity. It was appropriated with Bachman's theory [8]. He states that the test has content validity if the test design measured what should be measured in teaching learning process reflect to syllabus or instructional program. Therefore, the researcher arranged the test based on the syllabus and students' book. Moreover, it had been discussed with the colleague and the experts. It is congruent with Gay, et al. [9] opinion who state that content validity is determined by expert judgment. There is no formula or statistic by which it can be computed, and there is no way to express it quantitatively. It means that the instrument had been valid and could be used for measuring students' reading comprehension. The reliability of the reading test (Rii) was measured in a try out before using in pre-test, the mean score was $13,20(\mathrm{SD}=4,43)$. To get the realibility of the test, the researcher used Kuder-Richardshon 21 formula [9]. The reliability of the test was 0.81 which was indicated as an acceptable level of reliability.

For this research, the reading comprehension test score were used to analyze students' improvement by using Statistical Package for Social Science (SPSS), descriptive statistics were used to investigate the means and standard deviation of each variable. An independent $t$-test was analyzed to determine differences between the means of the experimental and control group. This also was used to determine whether there was a statistically significant difference after giving treatment between these groups. 


\section{FINDING AND DISCUSSION}

The result of the research findings were analyzed statistically by using SPSS to investigate whether there was any significant difference in scores in the experimental and control group before experiment, an independent t-test was conducted. The researcher could show her findings from the result of pre-test from both of groups in the Table I. According to the result of the mean and standard deviation, the mean score in the pre-test was $62.75(\mathrm{SD}=7.860)$ in the experimental group and $63.50(\mathrm{SD}=6.509)$ in the control group. There was no statistically significant difference in the mean score of the pre-test at the 0.05 level $(\mathrm{t}=-.329, \mathrm{p}>0.05)$. It was confirmed that the students between the two groups did not show any difference in reading comprehension proficiency. In can be concluded that these groups were homogenous, and they have the same level of reading comprehension ability.

To investigate statistically significant differences in reading comprehension improvement by the two groups after treatment, independent $t$-test were conducted. The result could be shown in the Table II. Table II describes that there is a statistically significant difference between the two groups on the post-test $(\mathrm{p}<0.05)$, but no such difference on the pre-test $(p>0.05)$. The mean score of the experimental group is 72.75 $(\mathrm{SD}=5.730)$, whereas the mean score of the control group was $65.5(\mathrm{SD}=6.262)$. It shows that the students in the experimental group significantly better on the post-test $(t=3.820, \mathrm{p}<0.05)$. It can conclude that the students using WhatsApp in blended learning showed higher score than those who did not.

Furthermore, comparing $t$-test 3.820 as mention in the Table II with the $t$-table 2.024 (df $38, \mathrm{p}<0.05$ ), we can conclude that $t$-test was higher than $t$-table. Therefore, the hypothesis $\mathrm{H}_{1}$ that stated there was a significant effect in blended learning through WhatsApp on EFL undergraduate students' reading comprehension was accepted. While $\mathrm{H}_{0}$ that stated there was not significant effect in blended larning through WhatsApp on EFL undergraduate students' reading comprehension was rejected.

Then, to investigate whether there was improvement in reading comprehension within the groups in the pre-test and post-test, the participants' reading comprehension test score were paired as in Table III.

TABLE I. RESUlT OF INDEPENDENT T-TEST : PRE TEST

\begin{tabular}{|l|r|r|r|r|r|r|}
\hline \multicolumn{1}{|c|}{ Group } & \multicolumn{1}{c|}{$\mathbf{N}$} & \multicolumn{1}{c|}{ Mean } & Std.Dev. & t-test & \multicolumn{1}{c|}{ Df } & P-Value \\
\hline \multirow{2}{*}{$\begin{array}{l}\text { Experimental } \\
\text { Control }\end{array}$} & 20 & 62.75 & 7.860 & -.329 & 38 & .744 \\
\cline { 2 - 7 } & 20 & 63.50 & 6.509 & & & \\
\hline
\end{tabular}

TABLE II. RESUlT OF INDEPENDENT T-TEST : POST TEST

\begin{tabular}{|l|r|r|r|r|r|r|}
\hline \multicolumn{1}{|c|}{ Group } & \multicolumn{1}{|c|}{ N } & \multicolumn{1}{c|}{ Mean } & Std. Dev. & t-test & Df & P-Value \\
\hline \multirow{2}{*}{$\begin{array}{l}\text { Experimental } \\
\text { Control }\end{array}$} & 20 & 72.75 & 5.730 & 3.8 & 3 & $.000^{* *}$ \\
\cline { 2 - 7 } & 20 & 65.5 & 6.262 & & & \\
\hline
\end{tabular}

TABLE III. THE COMPARISON OF CONTROL AND EXPERIMENTAL GROUP

\begin{tabular}{|l|l|l|l|l|c|}
\hline \multirow{2}{*}{ Group } & \multirow{2}{*}{$\mathbf{N}$} & \multicolumn{2}{c|}{ Pre-test } & \multicolumn{2}{c|}{ Post-test } \\
\cline { 3 - 6 } & & \multicolumn{1}{|c|}{ Mean } & Stdev & Mean & Stdev \\
\hline Control Group & 20 & 63.50 & 6.509 & 65.50 & 6.262 \\
\hline Experimental Group & 20 & 62.75 & 7.860 & 72.75 & 5.730 \\
\hline
\end{tabular}

From the table above, we can see the mean of the pre-test and post-test in the control group show improvement on the reading comprehension test, but not as significant as the results in the experimental group. The mean score of control group on the pre-test is $63.50(\mathrm{SD}=6.509)$ whereas the mean of the post-test is 65.50 ( $\mathrm{SD}=6.262$ ). While, the mean score of experimental group in pre-test is $62.75(\mathrm{SD}=7.860)$ and the post-test mean score is 72.75 ( $\mathrm{SD}=5.730)$. It means that, the students on the experimental group improved significantly on the reading comprehension test better than control group did. Almost all of the students in the experimental group got higher scores on the post-test because they had more reading practices and exercises not only in the classroom but also out of classroom through WhatsApp. They read many kind of texts, not only printed but also online texts. It improved their reading comprehension. This finding is congruent with Szymanska and Kaczmarek [8] concluded that the learners improved their achievement in a blended learning reading course by using both printed and online texts, it enhance the learners' reading comprehension.

Finally, the researcher assumes that applying blended learning through WhatsApp gave positive effect on EFL students' reading comprehension. It can be seen on the achievement of the students in experimental group that used WhatsApp in blended learning environment achieved higher scores than those who did not. They read more texts and interacted with their peers via WhatsApp, therefore it improved their reading comprehension. The researcher also interprets that blended learning through WhatsApp more successful than just face to face teaching and learning acitivities. The integration of mobile technology into a traditional face-to-face platform creates an optimal learning environment for language learning since it encourage students' interaction and autonomous learning out of classroom. In other words, blended learning through WhatsApp contributes to the achievement on EFL undergraduate students' reading comprehension.

\section{CONCLUSION AND RECOMMENDATION}

After conducting this research and analyzing the pre-test and post-test scores of both groups, it was obtain that $t$-test was 3.82 while the value of $t$-table was 2.024 , and the level of significant 0.05 . It means that $t$-test was higher than $t$-table. Therefore, the hypothesis $\mathrm{H}_{1}$ that stated there was a significant effect in blended learning through WhatsApp on EFL undergraduate students' reading comprehension was accepted. While $\mathrm{H}_{0}$ that stated there was not significant effect in blended larning through WhatsApp on EFL undergraduate students' reading comprehension was rejected. In conclusion, blended learning through WhatsApp contributes to the achievement of 
EFL undergraduate students' reading comprehension ability. Based on the findings of this study, the researcher recommends to the teachers and lecturers to use blended learning such WhatsApp for improving their students' reading comprehension because this method is appropriate in improving students' reading comprehension achievement.

\section{References}

[1] H. Farhady, A. Jafarpour, \& P. Birjandi, Language Skills Testing: From theory to practice, Tehran, Iran:SAMT Publishers, 1994.

[2] P. Neufeld, Comprehension Instruction in Content Area Classes. The Reading Teacher Journal. Vol. 59, pp.302-312, 2005.

[3] J.K. Klingner, Teaching Reading Comprehension to Students with Learning Difficulties, New York: The Guildford Press, 2007.

[4] S.J. Geddes, "Mobile Learning in the 21st Century: benefits for learners," Knowledge Tree E- journal, vol.30, no 3, pp. 214-228, 2004.

[5] F. Mikic, L. Anido, E. Valero, \& J. Picos, "Accessibility and mobile learning standardization," Paper presented at The Second International Workshop on MCL 2007, 2007.

[6] A. Kukulska-Hulme, "Will mobile learning change language learning?," ReCALL 21, 157-165, 2009

[7] E. Klopfer, K. Squire, \& H. Jenkins,. Enviromental Detectives: PDAs as a window into a virtual simulated world. In proceeding IEEE International Workshop on Wireless and Mobile Technologies in Education, Vaxjo, Sweden : IEEE Computer Society (pp. 95-98), 2002.

[8] A. Szymanka, \& A.W. Kaczmarek, Reading efficiency in blended learning context. Teaching English with Technology, 11 (2), 29-42. (Online) Retrieved from: www.tewtjournal.org/currectissues2011.htm ( April 10, 2016), 2011.

[9] L.F. Bachman, Fundamental considerations in language testing, Oxford University Press, 1990.

[10] L.R. Gay, G.E. Mills, P. Airasian, Educational Research. Competencies for analysis and applications, Pearson Education Ltd: London, 2009. 